\title{
KUALITAS KOKON ULAT SUTERA (Bombyx mori L.) RAS CINA, RAS JEPANG, DAN JENIS HIBRID DENGAN PAKAN DAUN MURBEI
}

\author{
(The quality of silk worm cocoon (Bombyx mori L.) of Chinese cocoon, Jepanese cocoon and \\ Hybrid cocoon with Murbei leaf as a feed)
}

\author{
Deni, Farah Diba, Gusti Eva Tavita \\ Fakultas Kehutanan Universitas Tanjungpura, Jalan Daya Nasional Pontianak, 78124 \\ Email: denid4272@gmail.com
}

\begin{abstract}
Silk worm cocoon is one of the non timber forest product which potential to develop in West Kalimantan. The aim of the research was to evaluate the best cocoon from silk worm consist of Chinese cocoon, Japanese cocoon and Hybrid cocoon with murbei leaf as a food source. The research was conducted in Silviculture laboratory in Forestry Faculty Tanjungpura University. The silk worm was preparation in laboratory condition until got instar III. When the silk worm got instar IV the sample of each silk worm from each types (Chinese, Japanese and Hybrid) with number 100 silk worm was separated for the evaluate on quality of the cocoon. The data of cocoon quality consist of the weight of fresh cocoon, the survival of silk worm, the amount of consumed the murbei leaf, percentage of cocoon skin and the percentage of fail cocoon. The quality of silk worm cocoon was based on SNI Standard from Balai Persuteraan Alam Indonesia. Result of the research showed that from the three type of silk worm cocoon, the silk worm from Chinese cocoon has the average values of percentage of skin cocoon around $22.1067 \%$ (included on Class B), cocoon weight was 0.9023 gram (included on Class D), and the percentage of fail cocoon was $22.50 \%$ (included on Class D). Meanwhile on silk worm from Japanese cocoon has the average values of percentage of skin cocoon around $18.9223 \%$ (included on Class C), cocoon weight was 1.21567 gram (included on Class C), and the percentage of fail cocoon was $5.4348 \%$ (included on Class C). Silk worm from Hybrid cocoon has the average values of percentage of skin cocoon around $22.8624 \%$ (included on Class B), cocoon weight was 1.3489 gram (included on Class $C$ ), and the percentage of fail cocoon was $4.1667 \%$ (included on Class C). The temperature for breeding the silk worm was $27-30^{\circ} \mathrm{C}$. The best cocoon quality was achieved from hybrid types.
\end{abstract}

Keywords: Chinese type, cocoon, Hybrid types, Japanese types, murbei, silkworm

\section{PENDAHULUAN}

Kalimantan Barat merupakan wilayah yang memiliki luasan hutan yang luas.Seiring berjalannya waktu keberadaan hutannya semakin berkurang karena deforestasi dan konversi lahan. Kegiatan pesuteraan alam merupakan salah satu upaya rehabilitasi lahan dan konservasi tanah, serta merupakan salah satu kegiatan yang dapat meningkatkan daya dukung dan produktivitas lahan terutama pada lahan-lahan yang belum optimal dimanfaatkan (Nurjayanti 2011). Produk yang dihasilkan dari tanaman murbei biasanya masyarakat hanya memanfaatkan dari buahnya, namun berjalannya perkembangan teknologi dan penelitian menunjukkan bahwa tanaman murbei ternyata memiliki ragam manfaat baik sebagai bahan pangan, obat-obatan atau kesehatan dan 
lingkungan (Isnan\& Muin 2015).Produk yang diperoleh dari pemeliharaan ulat sutera yang sudah dikenal oleh masyarakat umum adalah kain sutera dari benang sutera yang terbuat dari beberapa filamen kokon, selain itu juga kokon dapat dijadikan untuk kerajinan tangan dan kosmetik sebagai pelembab alami.

Pengelolaan murbei dan ulat sutera di Kalimantan Barat pernah dijadikan sebagai salah satu produk andalan yang dikembangkan oleh pemerintah Kabupaten Kubu Raya dengan bantuan dari

Kementerian

Kehutanan.Pengembangan ulat sutera dan murbei dicanangkan di Kecamatan Rasau Jaya menyusul masuknya investor dari China (Mulyani 2012). Kerjasama tersebut karena lokasi memiliki dua iklim yang sesuai dengan pengelolaan murbei dan ulat sutera sehingga pengelolaan murbei dan ulat sutera tidak bergantung pada musim dan diharapkan kualitas kokon lebih baik dari produksi kokon di Cina.Ada tiga jenis ulat yang dicoba budidayakan di Kalimantan Barat yaitu: Ras Cina, Ras Jepang dan jenis Hibrid yang juga merupakan jenis ulat yang diproduksi atau dikembangkan.Saat ini belum ada penelitian tentang jenis ulat yang lebih unggul potensinya dan sesuai dengan kondisi iklim di Provinsi Kalimantan Barat.Pertumbuhan dan perkembangan ulat sutera dipengaruhi oleh kualitas dan kuantitas tanaman murbei sebagai pakan (Muin et al 2015).

Tujuan dari penelitian yaitu melakukan pembudidayaan ulat sutera dengan 3 ras yang berbeda yaitu ras China, ras Jepang dan hybriddengan pemberian daun murbei sebagai pakan dan menganalisiskualitas kokon yang dihasilkan. Data yang dikumpulkan meliputi jumlah daun murbei yang dikonsumsi oleh ulat sutera, daya tahan hidup ulat sutera, bobot kokon segar, kualitas kokon, persentase kulit kokon, berat kokon, dan persentase kokon cacat. Hasil penelitian diharapkan dapat menjadi rekomendasi bagi penge mbangan pengelolaan budidaya ulat sutera di Provinsi Kalimantan Barat.

\section{METODE PENELITIAN}

Penelitian dilaksanakan di Laboratorium Silvikultur Fakultas Kehutanan Universitas Tanjungpura Pontianak kurang lebih 1 Bulan (Februari-Maret 2019). Penelitian dimulai dari penetasan telur sampai larva membentuk kokon.Penelitian menggunakan 3 ras ulat sutera yang berbeda yaitu Ras Cina, Ras Jepang, dan jenis Hibrid. Setiap ras dibudidayakan dengan pemberian pakan daun murbei. Pengamatan dimulai ketika ulat sudah memasuki ulat besar. Setiap Ras ketika sudah memasuki ulat besar atau sudah memasuki instar IV diambil sebanyak 100 ulat untuk dibudidayakan, kemudian dibagi dalam 5 ulangan sehingga dalam 1 tudung saji terdapat 20 ulat dipelihara. Hal ini bertujuan untuk mengetahui jumlah daun yang dimakan. Pengukuran suhu dan kelembaban dilakukan untuk mengetahui berapa kisaran suhu dan kelembaban ruangan pemeliharaan. 
Pencatatan dilakukan pada saat pemberian pakan. Pengujian kualitas kokon yaitu dengan cara mengambil masing-masing kokon setiap Ras sebanyak 10 kokon terdiri dari 5 kokon jantan dan 5 kokon betina. Kemudian dilakukan pengujian penimbangan, dan melakukan penyeleksian antara kokon jelek, kokon cacat, dan kokon baik.Kualitas kokon ditentukan oleh sifat keturunan dari jenis ulat sutera dan kondisi lingkungan seperti keadaan selama pemeliharaan, pengokonan, dll (Andadari dan Kuntadi 2014).

\section{HASIL DAN PEMBAHASAN}

Ulat sutera yang dibudidayakan di laboratorium berhasil berkembang biak dengan baik. Semua ulat berhasil membentuk kokon, baik pada ulat sutera ras China, ras Jepang dan hybrid.Setiap jenis ulat sutera menghasilkan bentuk kokon yang berbeda.Bentuk kokon dari tiga jenis ulat sutera yang berbedadisajikan pada Gambar 1.

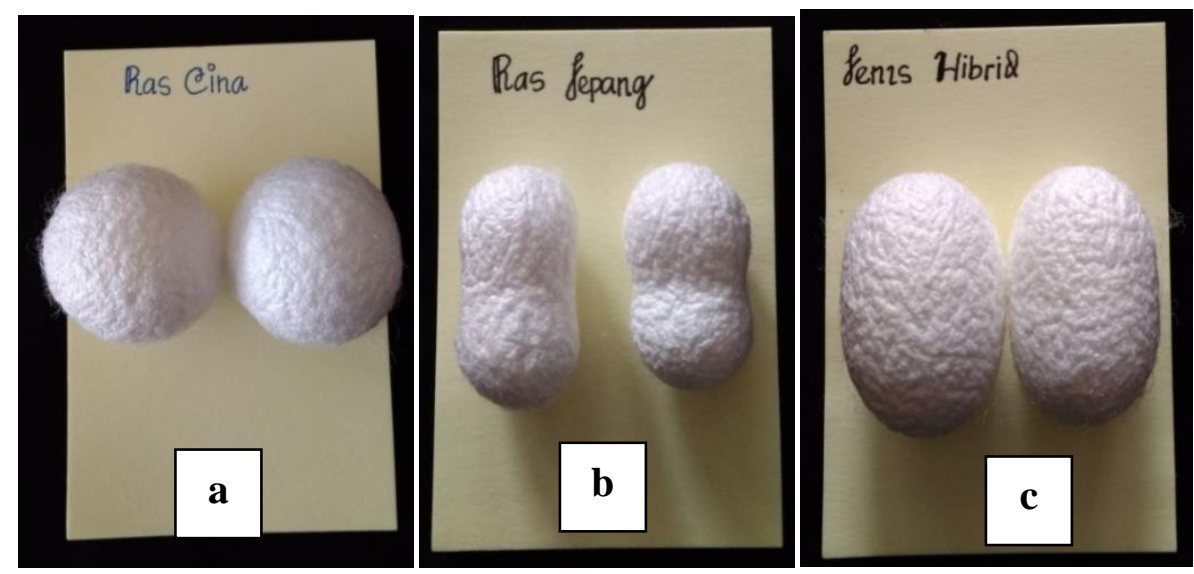

Gambar 1. Kokon ulat sutera dari tiga ras berbeda, $\mathrm{a}=$ ras China; $\mathrm{b}=$ ras Jepang; $\mathrm{c}=$ hybrid (The cocoon of silk worm from three types, $a=$ Chinese cocoon; $b=$ Japanese cocoon; $c=$ Hybrid cocoon)

Jumlah daun yang dikonsumsi oleh masing-masing jenis ulat dimulai dari instar IV sampai instar $\mathrm{V}$ masingmasing pada Ras Cina sebesar 185,42 gram dengan rata-rata 37,08 gram, Ras Jepang sebesar 210,84 gram dengan rata-rata 42,16 gram dan jenis Hibrid sebesar 207,04 gram dengan rata-rata
41,40 gram. Rata-rata jumlah pakan yang dikonsumsi per ekornya oleh ulat ras Cina adalah 1,854 gram, ras Jepang 2,108 gram, dan jenis hibrid 2.07 gram. Hasil perhitungan analisis sidik ragam konsumsi daun murbei sebagai pakan ulat sutera disajikan pada Tabel 1 . 
Tabel 1. Analisis sidik ragam konsumsi daun murbei oleh ulat sutera dengan ras berbeda, ras China, ras Jepang dan hybrid (The analysis of variance of murbei leaf consumption by silk worm with different type, Chinese type, Japanese type and hybrid type)

\begin{tabular}{|c|c|c|c|c|c|c|}
\hline $\begin{array}{c}\text { Sumber keragaman } \\
\alpha=5 \% \quad \alpha=1 \%\end{array}$ & & JK & KT & F.hitung & \multicolumn{2}{|c|}{ F.tabel } \\
\hline Perlakuan & 2 & 75,204 & 37,204 & $6,657 * *$ & 3,89 & 6,93 \\
\hline Galat & 12 & 67,057 & 5,589 & & & \\
\hline Total & 14 & 142,261 & & & & \\
\hline
\end{tabular}

Berdasarkan uji statistik tabel sidik ragam (uji $\mathrm{F}$ ) di atas diketahui bahwa $\mathrm{F}$ hitung $>\mathrm{F}$ tabel pada level nyata $(\alpha)=$ $1 \%$ (dengan tanda **) hal ini menunjukan bahwa pengaruh pemberian pakan daun murbei sangat nyata terhadap pertumbuhan ulat dan kualitas kokon yang dihasilkan.

\section{Suhu dan kelembaban}

Rataan suhu dan kelembaban selama pemeliharaan adalah suhu di pagi hari $28,1^{\circ} \mathrm{C}$ dengan kelembaban $82,05 \%$, Suhu di siang hari $29,12^{\circ} \mathrm{C}$ dengan kelembaban $82,58 \%$ Suhu di sore hari $29,3^{\circ} \mathrm{C}$ dengan kelembaban $82,65 \%$.Suhu di malam hari yaitu $28,87^{\circ} \mathrm{C}$ dengan kelembaban $82,42 \%$. Hasil rata-rata dari rataan suhu dan kelembaban menunjukan dalam pengembangan budidaya ulat sutera memiliki suhu dan kelembabannya cocok untuk budidaya ulat sutera, sehingga ulat dapat berkembang dengan baik, dan hidup sesuai dengan tahapan fasenya. Ulat sutera pada semua instar dapat hidup normal pada suhu maksimum $30^{\circ} \mathrm{C}$ dan minimum $20^{\circ} \mathrm{C}$, bahkan dapat bertahan pada suhu 33$35^{\circ} \mathrm{C}$, (Rahma et al2017). Kisaran suhu dalam penelitian adalah $27-30^{\circ} \mathrm{C}$, dan masih kisaran toleransi larva, ulat mampu hidup normal, dan cocok dalam budidaya ulat sutera.

\section{Daya tahan hidup ulat}

Daya tahan hidup ulat dilakukan dengan cara menghitung jumlah ulat yang mati atau tidak normal pada setiap instar. Urutan nilai daya tahan ulat pada akhir periode ulat besar instar $\mathrm{V}$ adalah Ras Cina sisa 87 ulat dari 100 ulat dimana (9 ulat hilang, 3 mati sakit, dan 1 kerdil), Ras Jepang sisa 97 ulat dari 100 ulat (3 ulat hilang), dan jenis Hibrid sisa 99 ulat (1 mati). Di bagian dari daya tahan hidup ulat sutera Ras Cina banyak sekali ulat yang hilang. Hilangnya ulat disebabkan karena dimakan oleh cicak di malam hari, dan ada yang mati karena sakit. Ciri-ciri ulat mati karena sakit warna kulitnya agak coklat kehitaman, badan agak membengkak dan mengeluarkan cairan dibagian mulut, seperti tumbuh jamur di bagian kulit, ada yang mati saat pergantian kulit, ada juga yang mati jatuh dari sasag lalu kena kerumun semut. 


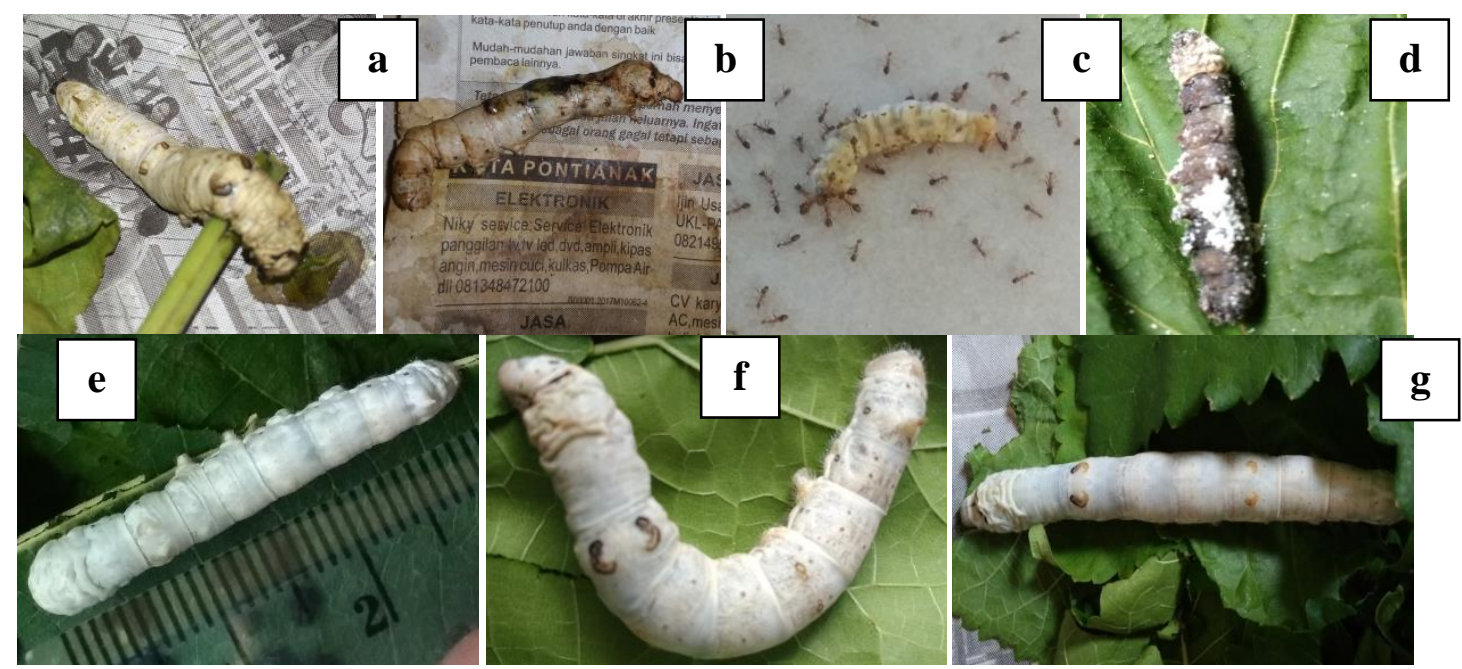

Gambar 2. Ulat sutera mati dan ulat sutera segar (fresh silk worm and died silk worm)

Keterangan:

(a). Ulat mati dengan ciri-ciri kulit berubah warna coklat agak kehitaman, badan agak mengembang, mengeluarkan cairan dimulut.

(b). Ulat mati dengan ciri-ciri warna kulit berubah menjadi agak kecoklat hitaman, kulit seperti berjamur, badan agak mengembabg, dan mengeluarkan cairan dimulut.

(c). Ulat mati jatuh dari sasag dan dikerumuni semut.

(d). Ulat mati saat ganti kulit.

(e). Ulat segar ras Cina.

(f). Ulat segar ras Jepang.

(g). Ulat segar jenis hibrid

\section{Bobot kokon segar}

Berdasarkan hasil uji dengan penimbangan sampel bobot kokon segar yang diperoleh dari masing-masing ulat sutera, ulat sutera jenis Hibrid memiliki nilai rata-rata berat kokon segar sebesar 1,74881 gram. Sementara ulat sutera ras Jepang memiliki rata-rata berat kokon segar 1,49939 gram, danulat sutera Ras
Cina memiliki rata-rata berat kokon segarnya 1,15838 gram.Ulat sutera jenis hibrid memiliki kualitas kokon yang lebih bagus karena nilai bobot kokon segarnya lebih tinggi dari ulat sutera Ras Jepang dan ulat sutera Ras Cina. Nilai rata-rata bobot kokon segar dari setiap jenis ras ulat sutera disajikan pada Gambar 3. 


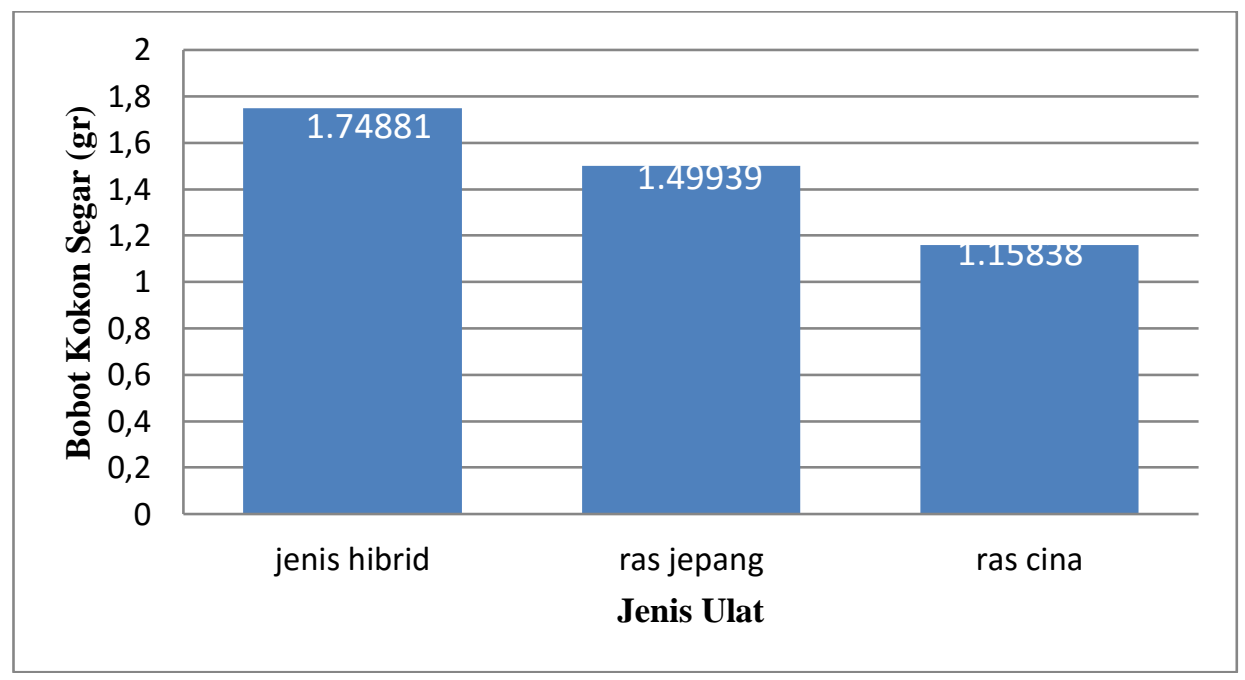

Gambar3. Bobot kokon segar ulat sutera dengan ras berbeda (The weight of cocoon of silk worm from three different types)

\section{Kualitas kokon}

Kualitas mutu kokon dibedakan menjadi kelas A, kelas B, kelas C dan kelas D berdasarkan berat kokonnya. Pembagian kelas mutu kokon berdasarkan standar mutu dari Balai Persuteraan Alam (2010) tentang persyaratan mutu kokon ulat sutera normal yang memenuhi standar mutu dari Negara Jepang dan Korea.Pembagian kelas mutu dihitung dari berat kokon yang dihasilkan oleh ulat sutera.Persyaratan kelas mutu disajikan pada Tabel 2.

Tabel 2. Persyaratan kelas mutu kokon ulat sutera normal (The requirement of quality of silk worm cocoon)

\begin{tabular}{ccccc}
\hline No & Kokon Cacat $(\%)$ & $\begin{array}{c}\text { Berat Kokon } \\
(\text { gram })\end{array}$ & Kulit Kokon $(\%)$ & Kelas \\
\hline 1 & $\leq 1,0$ & $\geq 2,0$ & $\geq 25$ & A \\
2 & $1,1-4,0$ & $1,5-1,9$ & $20-24,9$ & B \\
3 & $4,1-8,0$ & $1,0-1,4$ & $15-19,9$ & C \\
4 & $\geq 8,1$ & $\leq 0,9$ & $\leq 14,9$ & D \\
\hline
\end{tabular}

\section{Persentase Kulit Kokon}

Berdasarkan hasil penimbangan sampel kokonjenis Hibrid, rata-rata persentase kulit kokonnya sebesar 22,86\%. Nilai persentase kulit kokon ulat sutera jenis hybrid berdasarkan persyaratan kelas mutu termasuk dalam kelas B (20\% - 24,9\%).Sementara itu kokon dari ulat sutera Ras Cina memiliki rata-rata persentase kulit kokon sebesar22,10\%, dan masuk dalam kelas B (20\% - 24,9\%). Kokon ulat sutera Ras Jepangmemiliki ratarataberat persentase kulit kokon sebesar $18,92 \%$, masuk dalam kelas C (15\% $19,9 \%)$.Nilai rata-rata persentase kulit kokon ulat sutera disajikan pada Gambar 4. 


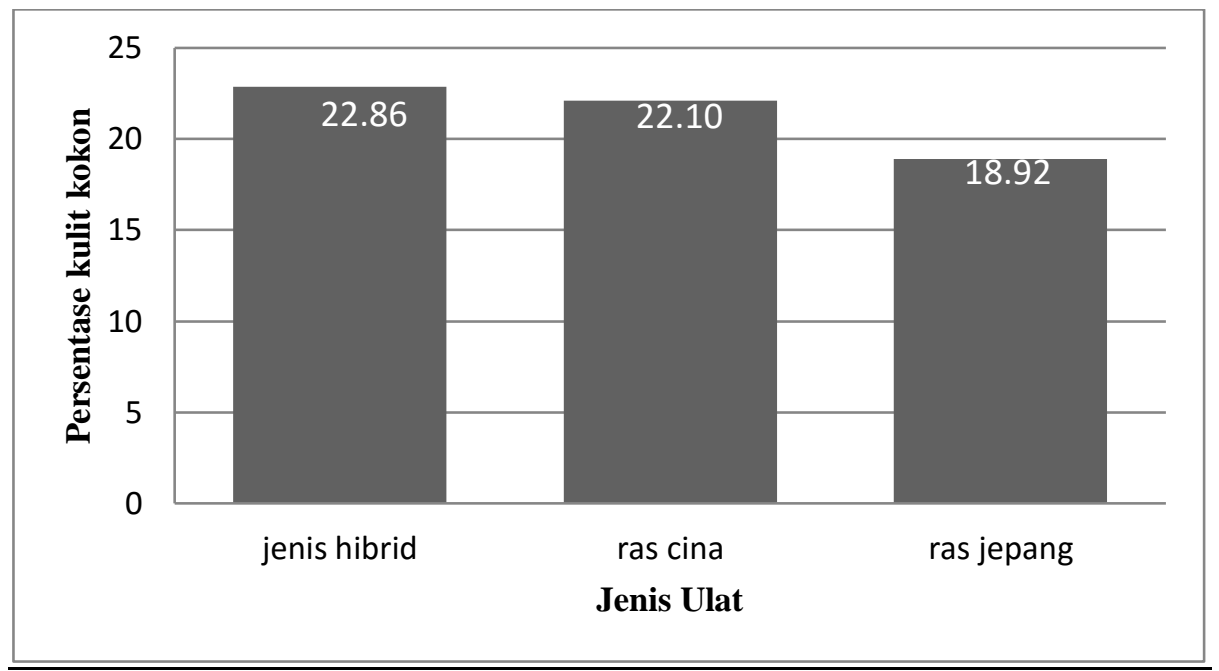

Gambar 4. Persentase kulit kokon ulat sutera dengan ras berbeda (The percentage of silk worm cocoon with three different types)

\section{Berat Kokon}

Berat kokon jenis Hibrid rata-rata sebesar 1,3489 gram dan masuk dalam kelas mutu kelas C (1,0 gram $-1,4$ gram). Sementara berat kokon Ras Jepang rata-rata sebesar 1,2156 gram, dan masuk dalam kualitas kelas $\mathrm{C}(1,0$ gram -1,4 gram). Berat kokon ulat sutera Ras Cina rata-rata sebesar 0,9023 gram, dan masuk dalam kualitas mutu kokon kelas $\mathrm{D}(\leq 0,9$ gram). Nilai ratarata berat kokon ulat sutera dari tiga ras yang berbeda disajikan pada Gambar 5.

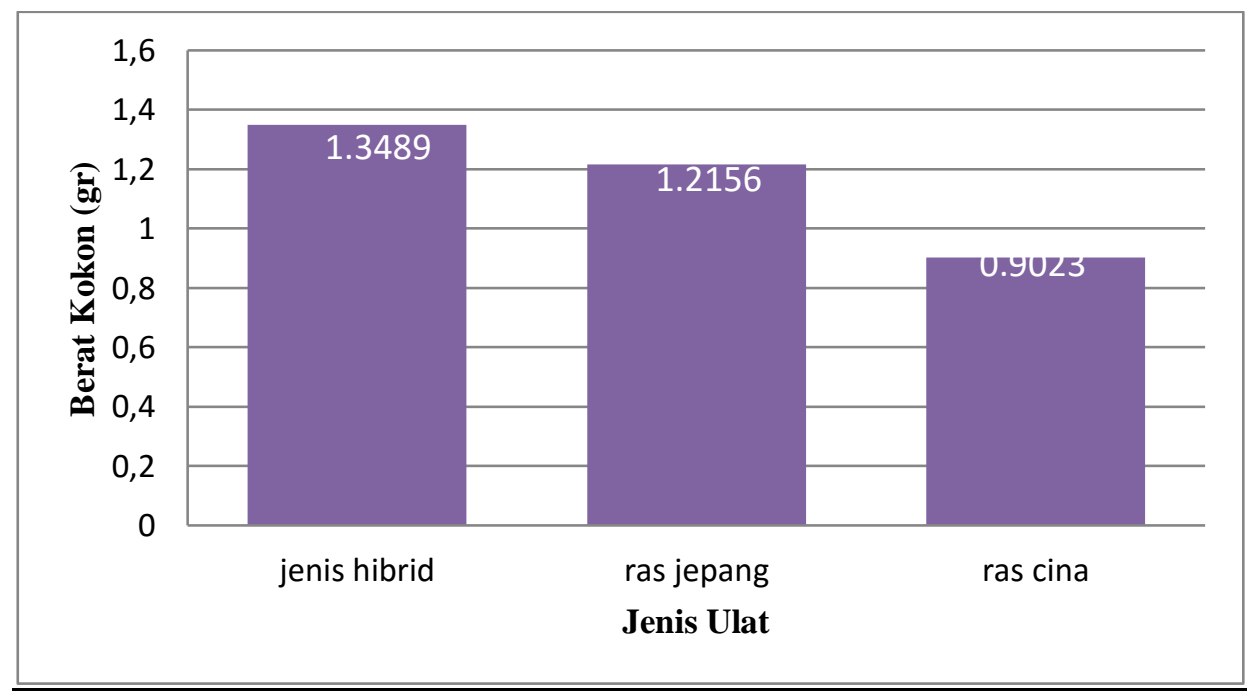

Gambar 5. Berat kokon ulat sutera dengan ras berbeda (the weight of silk worm cocoon from different types) 

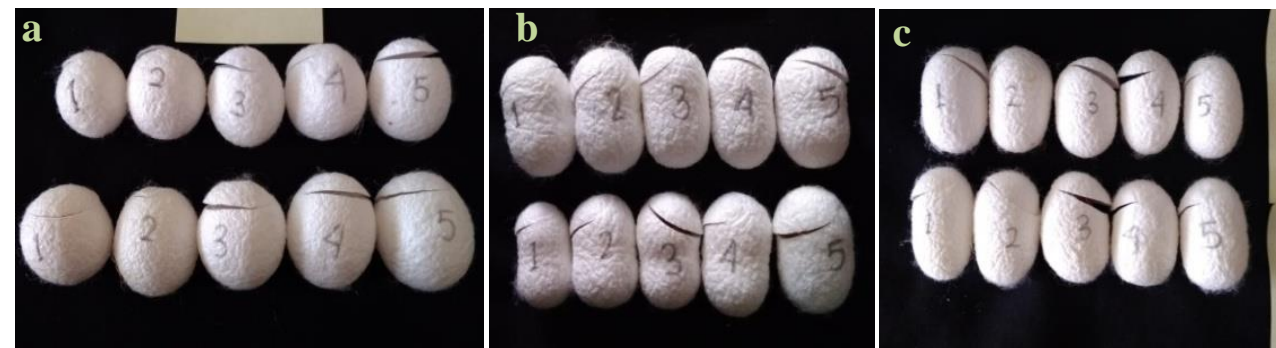

Gambar 6. Sampel kokon ulat sutera dengan ras berbeda, $a=$ ras China; $b=r a s$ Jepang; c=hybrid (sample of silk worm cocoon from different types, $a=$ Chinese cocoon; $b=$ Japanese cocoon; $c=$ Hybrid cocoon)

\section{Persentase Kokon Cacat}

Kokon cacat dianalisis darikokon yang dihasilkan oleh ulat sutera dari tiga jenis ulat yaitu ulat sutera ras China, ulat sutera ras Jepang dan ulat sutera hybrid.Kokon cacat meliputi kokon jelek (kokon kotor didalam, kotor diluar, kokon kulit tipis dan kokon berjamur), kokon cacat (kokon ganda/double, kokon berlubang, kokon berbulu, kokon berbentuk tidak normal, kokon cacat karena alat pengokonan, dan kokon ujung tipis).Hasil penelitian menunjukkan rata-rataulat sutera jenis
Hibrid memiliki kokon cacatsebesar $4,1667 \%$ dan termasuk dalam kelas mutu kelas C $(4,1 \%-8,0 \%)$. Sementara itu ulat suteraRas Jepang memiliki kokon cacat sebesar $5,4348 \%$ dan masuk dalam kualitas kelas C $(4,1 \%$ $8,0 \%)$. Kokon ulat sutera Ras Cinamemiliki nilai rata-rata $22,50 \%$ dan masuk dalam kelas mutu kelas D $(\geq$ $8,1 \%)$.Nilai rata-rata kokon ulat sutera yang cacat dari ketiga jenis kokon ulat sutera disajikan pada Gambar 7 dan bentuk cacat dari kokon ulat sutera disajikan pada Gambar 8.

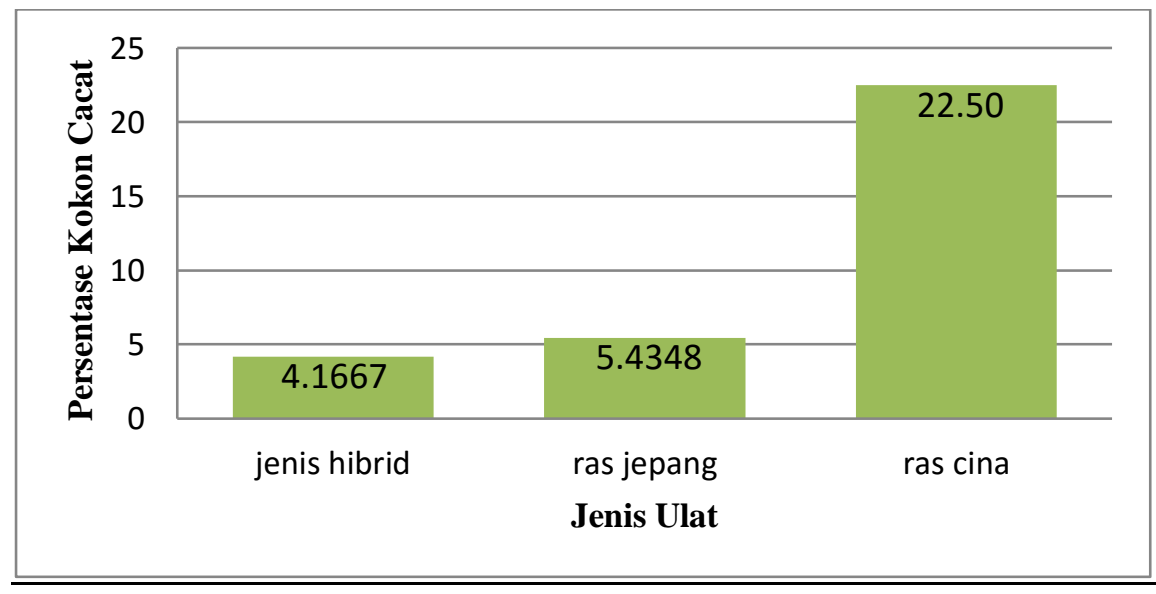

Gambar 7. Kokon cacat ulat sutera dengan ras berbeda (The cocoon of silk worm with three different types) 


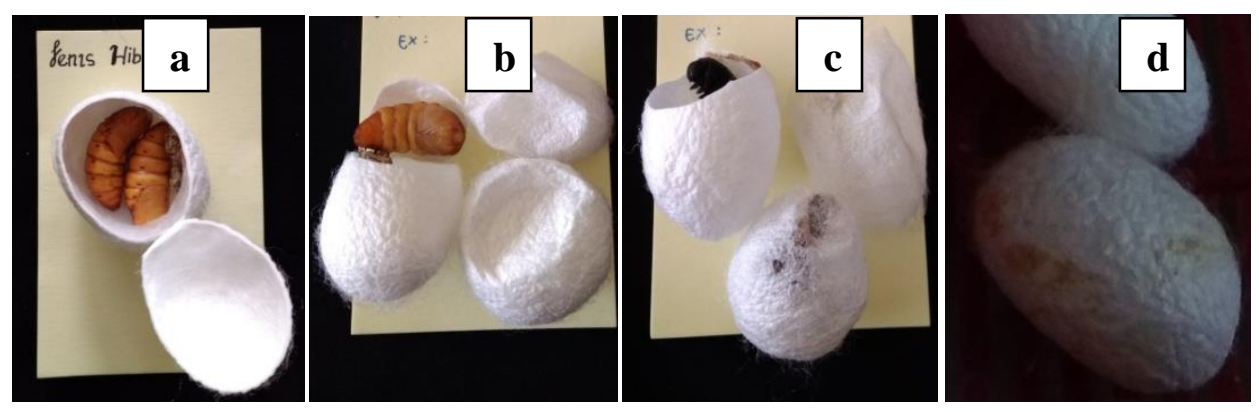

Gambar 8. Kokon ulat sutera yang cacat, $a=$ kokon ganda; $b=$ kokon tipis pupa hidup; $c=$ kokon tipis pupa mati; $d=$ kokon kotor (The fail cocoon of silk worm, $a=$ double cocoon; $b=$ thin $\operatorname{cocoon}$ with live pupa; $c=$ thin cocoon with died pupa; $d=$ dirty cocoon

Hasil penelitian menunjukkan kualitas kokon yang dihasilkan oleh ulat sutera dari ras hybrid lebih baik daripada kokon dari ulat sutera jenis ras China dan ras Jepang.Ulat sutera dapat dibudidayakan di daerah Provinsi Kalimantan Barat, khususnya di Kota Pontianak dan Kabupaten Kubu Raya.Habitat di kedua daerah tersebut cocok untuk pertumbuhan tanaman murbei sebagai pakan utama ulat sutera. Faktor yang mempengaruhi kualitas kokon adalah kualitas bibit, kualitas daun, kondisi pemeliharaan atau lingkungan, saat mengokon, seleksi kokon, penyimpanan dan pengangkutan kokon (Andadari dan Sunarti2015 ). Baik buruknya kualitas kokon yang telah diseleksi secara fisik diindikasikan oleh persentase kulit kokon, berat kokon dan persentase kokon cacat.Ulat sutera dari tipe hybrid direkomendasikan untuk pengembangan budidaya ulat sutera di Provinsi Kalimantan Barat.

\section{Kesimpulan}

1. Kualitas kokon ulat sutera yang dihasilkan oleh ulat sutera jenis hybrid lebih baik dari kokon ulat sutera jenis ras China dan ras Jepang.

2. Kualitas kokon yang dihasilkan dari ulat sutera dari ketiga ras yang berbeda menunjukan Ras Cina memiliki persentase kulit kokon sebesar 22,1067\% dan termasuk dalam kelas mutu Kelas B, berat kokonnya 0,9023 gram (kelas D), dan persentase kokon cacatnya $22,50 \%$ masuk dalam kelas D. Ulat sutera Ras Jepang memiliki persentase kulit kokon sebesar $18,9223 \%$ dan masuk dalamkelas mutu Kelas C, berat kokonnya 1,21567 gram (kelas C), dan persentase kokon cacatnya $5,4348 \%$ masuk dalam kelas $\mathrm{C}$. Ulat sutera jenis Hibrid memiliki persentase kulit kokon sebesar $22,8624 \%$ dan masuk dalam kelas mutu Kelas B, berat kokonnya1,3489 gram (kelas C), dan persentase kokon cacatnya 4,1667\% dan masuk dalam kelas C.

3. Pemberian pakan daun murbei pada ulat sutera mempengaruhi pertumbuhan ulat sutera serta kualitas kokon yang dihasilkan. 
Jumlah pakan yang dimakan oleh ulat sutera selama pemeliharaan dimulai dari instar ke IV pada ulat sutera Ras Jepang adalah 210,84 gram dengan rata-rata jumlah konsumsi 42,16 gram per ekor, jenis Hibrid 207,04 gram dengan rata-rata jumlah konsumsi 41,40 gram per ekor, dan Ras Cina 185,42 gram $r$ denganata-rata jumlah konsumsi 37,08 gram per ekor.

\section{Saran}

1. Pemeliharaan ulat ketika masih dalam bentuk larva harus benarbenar dijaga/dikontrol, ruangan tetap steril, agar larva terhindar dari penyakit dan ulat tidak banyak hilang dan mati karena diganggu serta dimakan oleh binatang lain seperti tikus, cicak, semut.

2. Sebaiknya dilakukan penelitian pengujian penyakit apa yang diderita oleh larva/ulat sehingga menyebabkan ulat mati.

3. Perlunya pemintalan kokon untuk mengetahui seberapa panjang benang atau filament yang dihasilkan.

\section{DAFTAR PUSTAKA}

Andadari L dan Kuntadi. 2014. Perbandingan Hibrid Ulat Sutera (Bombyx mori L.) Asal Cina dengan Hibrid Lokal Di Sulawesi Selatan. Jurnal Penelitian Hutan Tanaman Vol.11 No.3: Hal 173183

Andadari L dan Sunarti S. 2015. Kualitas Kokon Hasil Persilangan Antara Ulat Sutera (Bombyk mori
L.) Ras Cina dan Ras Jepang. Jurnal Pemuliaan Tanaman Hutan. Vol.9 No.1: Hal 43-51

Balai Pesuteraan Alam. 2010. Pedoman Teknik Budidaya Sutera Alam. Departemen Kehutanan, Direktorat Jendral Rehabilitasi Lahan dan Pertumbuhan Sosial.

Isnan W dan Muin N.2015."Tanaman murbei" sumber daya hutan multimanfaat. Info teknis Eboni 12 No. 2: $111-119$

Mulyadi. 2012. Kemenhut Bantu Kubu Raya Kembangkan Ulat Sutera. https://kalbar.antaranews.com/beri ta/308045/kemenhut-bantu-kuburaya-kembangkan-ulat-sutera [01 April 2019]

Muin N, Suryanto H, dan Minarningsih. 2015. Uji Coba Hibrid Morus Khunpai dan M. Indica Sebagai Pakan Ulat Sutera (Bombyx mori Linn.). Jurnal Penelitian Kehutanan Wallacea. Vol. 4 No.2: $137-145$

Nurjayanti ED. 2011. Budidaya Ulat Sutera dan Produksi Benang Sutera Melalui Sistem Kemitraan Pada Pengusahaan Sutera Alam (PSA) Regaloh Kabupaten Pati.MEDIAGRO. Vol. 7 No. 2: Hal $1-10$

Rahma F, Moerfiah, dan Andadari L. 2017. Pertumbuhan dan Kualitas Kokon Ulat Sutera (Bombyx mori) Daun Murbei (Morus cathayana) dan Daun Murbei Hibrid Suli-01. Jurnal Online Mahasiswa (JOM) $\begin{array}{lll}\text { Bidang Biologi. } & \text { Vol.3 No.3 }\end{array}$ 